\title{
Exchange of Carbon Dioxide between the Atmosphere and the Maize Field Fertilized with Digestate from Agricultural Biogas Plant
}

\author{
Robert Czubaszek \\ 1 Department of Agri-Food Engineering and Environmental Management, Faculty of Civil and Environmental \\ Engineering, Białystok University of Technology, ul. Wiejska 45A, 15-351 Białystok, Poland \\ e-mail: r.czubaszek@pb.edu.pl
}

\begin{abstract}
The aim of the research was to determine the exchange rate of carbon dioxide between the atmosphere and the maize field fertilized with the digestate from an agricultural biogas plant. The studies considered both the amount of net carbon dioxide emission which is the difference between the amount of this gas absorbed by vegetation and its amount emitted from the whole ecosystem of the field as well as the emission resulting only from the changes occurring in the soil. The $\mathrm{CO}_{2}$ emission from the entire field was measured by the eddy covariance method with a set of LI-7500A analyzer (LI-COR Biosciences, USA) for measuring the $\mathrm{CO}_{2} / \mathrm{H}_{2} \mathrm{O}$ concentration in air and 3-axis WindMaster ultrasonic anemometer (GILL, UK). The data from the analyzers were recorded at $10 \mathrm{~Hz}$, while the $\mathrm{CO}_{2}$ streams were calculated using the EddyPro 5 software. The soil emission was determined with the chamber method using the automated ACE measurement system (ADC BioScientific, UK). Until the maize reached maturity, the study was carried out once a week, at $10.00-14.00$. During each measurement day, the basic meteorological parameters were measured as well. The obtained results showed a clear relationship between the plants development phase and the size of the net $\mathrm{CO}_{2}$ exchange. The negative values of carbon dioxide streams, indicating the absorption of this gas from the atmosphere, were observed already in the case of plants with a height of approx. $25 \mathrm{~cm}$, while the maximum values were reached after the release of panicles by maize. The carbon dioxide emission from soils, measured at the same time, was maintained throughout the entire research period at a similar low level, undergoing only slight fluctuations associated with variable soil moisture. The study showed that the maize field, almost throughout all growing season, can be treated as a sink of atmospheric carbon dioxide, reducing its emission from agriculture.
\end{abstract}

Keywords: carbon dioxide, agricultural biogas plant, digestate

\section{INTRODUCTION}

Agriculture is responsible for around 12\% of the global greenhouse gas emissions, being the main source of methane and nitrous oxide emissions [Smith et al. 2014]. Emissions of these gases from agriculture are associated with several processes: enteric fermentation of livestock $\left(\mathrm{CH}_{4}\right)$, emission from animal manure $\left(\mathrm{CH}_{4}\right.$ and $\mathrm{N}_{2} \mathrm{O}$ ), emission from agricultural soils $\left(\mathrm{N}_{2} \mathrm{O}\right)$ and burning of plant residues $\left(\mathrm{CH}_{4}\right.$ and $\left.\mathrm{N}_{2} \mathrm{O}\right)$ [KOBIZE 2016]. Most agricultural $\mathrm{CO}_{2}$ emissions are from land conversion and fossil fuel use [Gelfand, Robertson 2015].
Considering the necessity of a significant reduction of GHG by 2030, essential to meet the climate targets set up by EU leaders, the role of agriculture in this process seems to be crucial [Albiac et al. 2017]. Excluding the agricultural emissions from the mitigation measures will increase the mitigation costs, as compared to other sectors of the economy. Agriculture provides cheap alternatives to reducing greenhouse gas emissions [Reisinger et al. 2013]. In addition, the need to mitigate the greenhouse gas emissions in agriculture is becoming particularly important in the light of the intensification of agriculture required to feed the growing world population [Tilman et 
al. 2011]. Despite these obvious facts, the role of terrestrial ecosystems, including agricultural land, in mitigating the increase of $\mathrm{CO}_{2}$ concentration in the atmosphere remains underappreciated [Pawłowski et al. 2017].

Agricultural activities can mitigate the GHG emissions by increasing the sequestration of $\mathrm{C}$ in soil organic matter and plant biomass and by using sustainable agricultural biofuels [CAST 2011]. One of the ways to reduce the greenhouse gas emissions from agricultural areas is to cultivate the plants, which on the one hand can absorb atmospheric carbon dioxide in the photosynthesis process, and have biomass that could constitute a renewable source of energy on the other, thus helping to reduce the demand for conventional energy sources. Maize is an example of a plant that can perform both tasks; it has relatively high carbon fixation and assimilation capacity and, even under the conditions of drought, high temperatures and nitrogen or $\mathrm{CO}_{2}$ limitations, it exhibits water-use efficiency properties [Arodudu et al. 2017]. Maize is the most popular cereal worldwide with increasing sown area due to multiple possibilities of its use. Maize can be grown for grain used for the production of articles for human consumption and for livestock feed. In recent years in Poland, in most voivodeships there has been a decrease in the area of fields sown for maize grain, whereas the area of maize cultivated for green forage is systematically growing. This trend in maize production is mostly pronounced in the Podlaskie Voivodeship, in which the sown area for green forage increased in 2006-2016 more than twice and is currently one of the largest in Poland [LDB 2018]. It is connected with intensive cattle breeding, for which ensiled maize forms the basis of nutrition.

Maize is also one of the most relevant energy crops for the biogas production. Its main advantage is the relatively high yield of green mass per 1 ha, good susceptibility to ensiling and the production of biogas and methane at a stabilized level [Szlachta, Tupieka 2013]. However, biogas plant is not just an energy producer, but it also constitutes a source of valuable organic fertilizer, the use of which can significantly contribute to reducing the need for mineral fertilizers. One of the most important characteristics of digestate, along with a beneficial effect on soil physical and chemical properties [Nkoa 2014, AndersonGlenna, Morken 2013], is the fact that during anaerobic digestion, total nutrient content remains the same, but their respective forms are changed into inorganic forms that are readily available to plants [Crolla et al. 2013].

Whether or not a given ecosystem is a source or a reservoir of carbon dioxide can be indicated by value of net ecosystem exchange (NEE) between the biosphere and the atmosphere. NEE corresponds to the net difference of photosynthetic carbon uptake and the respiration of autotrophs and heterotrophs [Reichstein et al. 2012]. In brief, the negative NEE values indicate net assimilation or $\mathrm{CO}_{2}$ uptake, whereas the positive NEE values indicate net respiration or $\mathrm{CO}_{2}$ loss [Chen et al. 2014]. A large share in this exchange process, beside photosynthesis, is also represented by soil respiration, which consists of root respiration, heterotrophic respiration, soil fauna respiration and non-biological $\mathrm{CO}_{2}$ production [Xu, Shang 2016].

There are two common approaches for measuring NEE - eddy covariance (EC) and chamber methods. The eddy covariance method is an example of a micrometeorological technique that measures fluxes at large-scale level directly, in contrast to methods where the flux is deduced from the change of concentration over time inside an enclosure [Eugster, Merbold 2015]. Conversely to this method, chamber systems quantify fluxes over smaller areas but are more useful for $\mathrm{CO}_{2}$ partitioning studies [Hafner et al. 2012]. The combination of these two methods can be used to determine the share of gas exchange associated only with the processes occurring in the soil in the gas exchange of the entire ecosystem.

The aim of the research was to determine the size and nature of the $\mathrm{CO}_{2}$ exchange between the atmosphere and the maize field fertilized with the digestate from an agricultural biogas plant as well as to determine to what extent the soil respiration rate contributes to the total exchange.

\section{MATERIALS AND METHODS}

The research was conducted in a field located near the Ryboły village in the Podlaskie Voivodeship, Poland, in the period from 08.05.2017 to 30.10.2017 r. During the field work, the height of randomly selected plants was measured and photographs were taken to determine the coverage of the field by vegetation. This coverage was calculated using the CorelDRAW Graphics Suite X3 graphics package. 
In order to determine the soil properties in the analyzed field, the soil samples were taken from $20 \mathrm{~cm}$ of the arable layer. The samples were airdried, sieved to $2 \mathrm{~mm}$ and analyzed for basic soil properties: texture (determined on the basis of hydrometer method), $\mathrm{pH}$ (measured in 1:25 soil/ water suspension ratio with HQ40D meter, Hach, USA), organic carbon content (measured with TOC-L analyzer equipped with SSM-5000A Solid Sample Combustion Unit, Shimadzu, Japan), total nitrogen (measured with VAP50s analyzer, Gerhardt, Germany) and the plant-available phosphorus $\left(\mathrm{P}_{2} \mathrm{O}_{5}\right)$ and potassium $\left(\mathrm{K}_{2} \mathrm{O}\right)$ (both determined after extraction with calcium lactate solution).

The soil on the study field was classified as Luvisols [WRB 2015] with a texture of loamy sand and slightly acidic $\mathrm{pH}$ (Table 1). The quite narrow $\mathrm{C} / \mathrm{N}$ ratio is typical for properly used agricultural soils and suggests quick decomposition of organic matter and production of nitrogen essential for microbes. The studied soil is also rich in the plant available forms of main elements, especially phosphorus.

The digestate was distributed on the surface of the study field at the beginning of the March in an approximate amount of $30 \mathrm{~m}^{3} \mathrm{ha}^{-1}$. Its characteristics were typical for the material produced by anaerobic decomposition of organic matter during the biogas production in agricultural biogas plants fed with maize silage. It had the total solids (TS) content of $7.2 \pm 0.3 \%$ (determined via the weight method by oven-drying at $105^{\circ} \mathrm{C}$ ), volatile solids (VS) content equal to $72.6 \pm 0.3 \% \mathrm{TS}$ (determined via the weight method by ignition at $550^{\circ} \mathrm{C}$ in a muffle furnace), $\mathrm{pH}$ of $7.9 \pm 0.1$, (measured with a HQ40D meter, Hach, USA). It had organic the carbon content of $28.1 \pm 0.9 \mathrm{~g} \mathrm{~kg}^{-1}$ of fresh mass (FM) (measured with a TOC-L analyzer equipped with SSM-5000A Solid Sample Combustion Unit, Shimadzu, Japan), the nitrogen content of $4.4 \pm 0.2$ $\mathrm{g} \mathrm{kg}^{-1}$ FM (measured with a VAP50s analyzer, Gerhardt, Germany) and phosphorus content of $0.8 \pm 0.1 \mathrm{~g} \mathrm{~kg}^{-1} \mathrm{FM}$ (measured via the vanadatemolybdate method after sample mineralization in a microwave oven (ETHOS One, Milestone, Italy).
The gas exchange research included 15 measurements carried out between 10 a.m -2 p.m. At the beginning, they were performed weekly; later the intervals between measurements were extended to 2-3 weeks due to stable meteorological conditions and no changes in the plant cover. The fluxes of $\mathrm{CO}_{2}$ from the whole field were measured with EC system which consisted of LI-7500A (LI-COR Biosciences, USA), open-path analyzer to measure $\mathrm{CO}_{2} / \mathrm{H}_{2} \mathrm{O}$ concentrations and sonic anemometer (WindMaster, GILL, UK) to measure three-dimensional wind speed, wind direction and sonic temperature. The data from EC sensors were recorded using data logger (Xlite 9210 Datalogger, Sutron, USA). During the measurements of fluxes, microclimate of the study field was analyzed with the following set of sensors connected to the data logger: quantum sensor (LI-190SL-50, LI-COR, USA), air temperature and relative humidity probe (HMP155, Vaisala, Finland), three soil temperature and water content sensors (Hydra Probe II, Stevens Water Monitoring System Inc., USA). All sensors were fixed $200 \mathrm{~cm}$ above the ground or canopy layer. The data was measured with a frequency of $10 \mathrm{~Hz}$.

The soil respiration was measured by means of the chamber method with automatic system ACE (ADC BioScientific, UK). The device operated in an open mode, in which the net $\mathrm{CO}_{2}$ exchange rate is determined on the basis of the rate of change of $\mathrm{CO}_{2}$ concentration of the gas in the chamber during assay. The volume of the chamber was 11 and it was fitted with a collar inserted in the soil, without vegetation at the depth of $3 \mathrm{~cm}$. The measurements were carried out every 20 minutes.

\section{RESULTS AND DISCUSSION}

The research on the gas exchange over the studied area during the first two measurement days (May 8th and May 15th) was conducted on an empty field, before the appearance of maize, which was planted in an average of 12 plants

Table 1. Basic soil properties

\begin{tabular}{|c|c|c|c|c|c|c|c|c|c|}
\hline \multicolumn{3}{|c|}{ Soil fraction [mm] } & \multirow{2}{*}{\multicolumn{2}{|c|}{$\mathrm{pH}$}} & \multirow{2}{*}{ C } & \multirow{2}{*}{$\mathrm{N}$} & \multirow{3}{*}{$\mathrm{C} / \mathrm{N}$} & & \multirow{2}{*}{$\mathrm{K}_{2} \mathrm{O}$} \\
\hline $0,05-2$ & $0,002-0,05$ & $<0,002$ & & & & & & $P_{2} \mathrm{U}_{5}$ & \\
\hline \multicolumn{3}{|c|}{ Content of soil fraction [\%] } & $\mathrm{H}_{2} \mathrm{O}$ & $\mathrm{KCl}$ & \multicolumn{2}{|c|}{$\left[\mathrm{g} \mathrm{kg}^{-1}\right]$} & & \multicolumn{2}{|c|}{ [mg $\left.100 \mathrm{~g}^{-1}\right]$} \\
\hline $80 \pm 1$ & $19 \pm 1$ & $1 \pm 1$ & $6.6 \pm 0.2$ & $5.8 \pm 0.1$ & $9.9 \pm 1.2$ & $0.9 \pm 0.1$ & $10.8 \pm 0.6$ & $46,0 \pm 5.8$ & $24,7 \pm 2.9$ \\
\hline
\end{tabular}

Explanations: $\mathrm{pH}$ - reaction, $\mathrm{C}$ - total organic carbon, $\mathrm{N}$ - total nitrogen content, $\mathrm{P}_{2} \mathrm{O}_{5}$ - plant-available phosphorus, $\mathrm{K}_{2} \mathrm{O}$ - plant-available potassium. 
per $\mathrm{m}^{2}$. On the third day (May 22nd), maize was already $10 \mathrm{~cm}$ high and covered about $3 \%$ of the area (Figure 1).

A week later, the plants were already $25-30 \mathrm{~cm}$ high and covered about $10 \%$ of the field's area. Over the next two weeks, the growth of plants was relatively fast and on June 12th they reached about $65 \mathrm{~cm}$ in height, while the cover increased to only $20 \%$. A significant change in coverage was observed a week later, when plants reached height of $85-100 \mathrm{~cm}$ and covered $60 \%$ of a field. Over the next week maize grew to about $130 \mathrm{~cm}$ and covered about $75 \%$ of the area. From that moment on, the cover did not change, despite the fact that the height of maize increased. Plant reached the maximum height $(230-250 \mathrm{~cm})$ on July $24 \mathrm{th}$. Plants had already developed cobs and entered the flowering phase. Over the next three months, maize remained in the field and was harvested in the last week of October. During the measurements performed at the beginning of September, maize was still mostly green, while on October 17th plants were yellow and dry.

The gas exchange in the test field was closely related to the development of vegetation. The field without the plant cover was a source of carbon dioxide released from the soil as a result of the processes occurring in it after the introduction of the easily decomposed organic matter in the form of the digestate from an agricultural biogas plant. However, it should be noted that despite fertilization, the soil emission was low and comparable to a typical agricultural soil. This was probably caused by relatively low soil moisture [Pezzolla et al. 2012]. Additionally, as evidenced by previous research, the emission related to the introduction of digestate has a short-lived nature and is clearly visible only during its distribution on the field surface [Czubaszek, Wysocka-Czubaszek 2018].

The biomass production phase is the only time when carbon dioxide is captured from the atmosphere in photosynthesis. Due to this process, vegetation has a large share in the reduction or even in negative $\mathrm{CO}_{2}$ footprint values [Budzianowski, Postawa 2017]. The first signs of atmospheric $\mathrm{CO}_{2}$ assimilation, manifested by the negative values of the carbon dioxide fluxes measured above the test field, were observed already a week after the maize appearance (May 30 th), when plants covered only $10 \%$ of the field (Figure 2). It was much more evident three weeks later (June 19th), while the highest $\mathrm{CO}_{2}$ absorption by the maize field was recorded on July $24^{\text {th }}$, when maize entered the release of panicles stage. After reaching the maximum height by plants, the field still accumulated atmospheric carbon dioxide until the maize was green. The size of the $\mathrm{CO}_{2}$ fluxes approached the amount emitted by the soil itself in mid-September, when the maize became dry. The obtained results are consistent with those shown by Zhang et al. [2015], who studied the exchange of carbon dioxide in various ecosystems, including the maize field, which turned out to have the largest carbon absorption capacity and constituted a $\mathrm{CO}_{2}$ sink throughout the growing season.

The process of carbon dioxide assimilation by vegetation was favored by the weather conditions observed during the measurement days (Table 2), especially the values of photosynthetic active radiation, which almost always exceeded $1200 \mu \mathrm{mol} \mathrm{m}^{-2} \mathrm{~s}^{-1}$, and which during the growing season is the most important factor for regulating

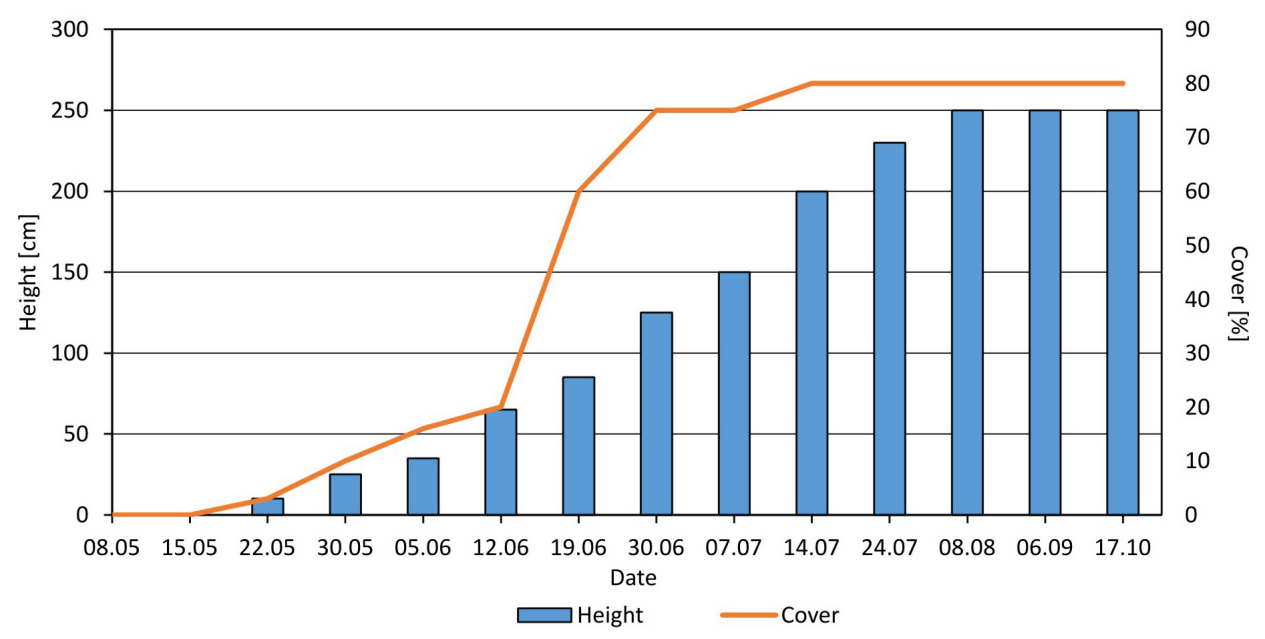

Figure 1. The development of vegetation in the field under investigation 


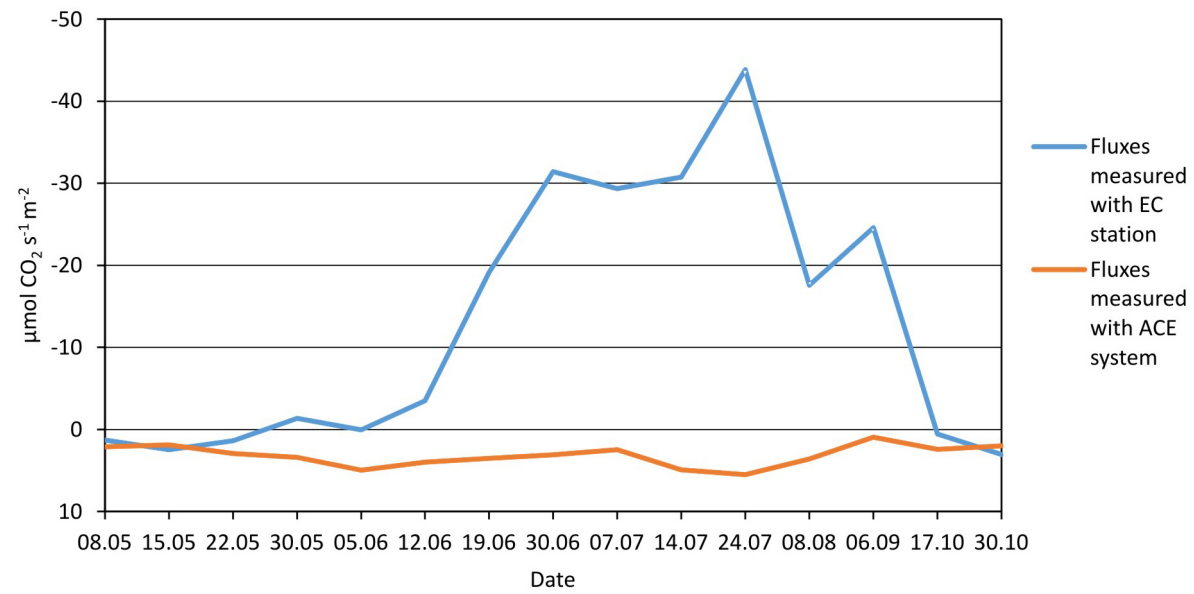

Figure 2. Exchange of carbon dioxide between the studied field and the atmosphere

Table 2. Selected microclimatic conditions

\begin{tabular}{|c|c|c|c|c|c|}
\hline \multirow{2}{*}{ Date } & Ta & RH & PPFD & SWC & Ts \\
\cline { 2 - 6 } & {$\left[{ }^{\circ} \mathrm{C}\right]$} & {$[\%]$} & {$\left[\mu \mathrm{mol} \mathrm{m}^{-2} \mathrm{~s}^{-1}\right]$} & {$\left[\mathrm{m}^{3} \mathrm{~m}^{-3}\right]$} & 0.30 \\
\hline $2017-05-08$ & 11.70 & 57.74 & 1234.39 & 0.13 & 24.93 \\
\hline $2017-05-15$ & 20.17 & 33.71 & 1731.05 & 0.13 & 26.20 \\
\hline $2017-05-22$ & 18.53 & 53.07 & 1524.38 & 0.05 & 24.30 \\
\hline $2017-05-30$ & 17.40 & 67.69 & 874.51 & 0.20 & 21.11 \\
\hline $2017-06-05$ & 17.74 & 62.16 & 1260.94 & 0.07 & 22.19 \\
\hline $2017-06-12$ & 19.53 & 62.20 & 500.30 & 0.08 & 33.16 \\
\hline $2017-06-19$ & 25.49 & 55.03 & 1592.77 & 0.21 & 23.46 \\
\hline $2017-06-30$ & 22.56 & 54.10 & 1398.06 & 0.13 & 29.30 \\
\hline $2017-07-07$ & 19.66 & 41.55 & 1670.88 & 0.14 & 24.33 \\
\hline $2017-07-14$ & 18.87 & 55.29 & 1323.20 & 0.18 & 24.00 \\
\hline $2017-07-24$ & 24.55 & 54.32 & 1457.05 & 0.02 & 28.87 \\
\hline $2017-08-08$ & 23.97 & 39.13 & 1240.79 & 0.17 & 16.90 \\
\hline $2017-09-06$ & 13.61 & 67.71 & 775.15 & 0.18 & 14.07 \\
\hline $2017-10-17$ & 13.75 & 90.86 & 221.00 & 0.15 & 15.21 \\
\hline $2017-10-30$ & 11.15 & 89.25 & 230.18 & \\
\hline
\end{tabular}

Explanations: Ta - air temperature, RH - air relative humidity, PPFD - photosynthetic photon flux density, SWC - soil water content, Ts - soil surface temperature.

the daytime ecosystem $\mathrm{CO}_{2}$ exchange [Lei, Yang 2010]. On the other hand, high soil surface temperature, close up to $30^{\circ} \mathrm{C}$, could have contributed to higher emissions and to higher soil respiration rates resulting from the increased microbial metabolism [Oertel et al. 2016].

The research on the soil respiration conducted simultaneously with the measurements covering the entire field of maize has shown that throughout the growing season, soil was a source of carbon dioxide. The obtained results confirm the findings of Chen et al. [2014], whose NEE measurements conducted in a field devoid of vegetation showed the release of carbon dioxide throughout the research period. A small variation in soil respiration obtained in the presented research could be related to the differences in soil moisture, which were described by Wolf et al. [2011] as the main environmental control of daytime NEE, alongside radiation.

In the case of the tested field, the previously described positive effect resulting from intensive $\mathrm{CO}_{2}$ uptake by the growing maize, is only one of the effects in terms of the possibility of GHG emissions reduction. Cultivated maize is used as a substrate in an agricultural biogas plant placed next to field, while the digestate remaining after the biogas production is used for maize fertilization. As shown by Gerin et al. [2008] the production of energy from maize enables a significant reduction of $\mathrm{CO}_{2}$ resulting from the use of fossil fuels, despite its consumption at the stage of maize production and its transformation into biogas. However, this reduction will be lower in the case of intensive fertilization or intensive cultivation. 
Despite these obvious benefits, it should be remembered that using maize for biogas production reduces its amount that can be used for other purposes, primarily as animal feed. The study conducted by Hamelin et al. [2014] showed that maize silage had the highest biogas potential among the investigated substrates; at the same time, including the indirect land use change (ILUC) into assessment this substrate caused an increase of net GHG emission.

\section{CONCLUSIONS}

Maize, due to the high degree of coverage of the field with vegetation, was the storage of atmospheric carbon dioxide throughout the growing season, thus reducing the emission of this gas from agriculture. The absorption of carbon dioxide by vegetation was the highest in the phase of maximum plant growth, but it was already pronounced at the early stage of vegetation development. Despite the fertilization of the studied field with digestate from an agricultural biogas plant providing an easily decomposed organic matter, the carbon dioxide emission associated with the transformation of these substances in the soil was even throughout the research period and had a small share in the gas exchange between the field and the atmosphere.

\section{Ackonwledgments}

This work was financially supported by Ministry of Science and Higher Education as a part of the project $\mathrm{S} / \mathrm{WBiIS} / 01 / 17$.

\section{REFERENCES}

1. Albiac J., Kahil T., Notivol E., Calvo E. 2017. Agriculture and climate change: Potential for mitigation in Spain. Science of the Total Environment, 592, 495-502.

2. Anderson-Glenna M., Morken J. 2013. Greenhouse gas emissions from on-farm digestate storage facilities. Tel-Tek report no. 2213040-1, Norway.

3. Arodudu O. T., Helming K., Voinov A., Wiggering H. 2017. Integrating agronomic factors into energy efficiency assessment of agro-bioenergy production A case study of ethanol and biogas production from maize feedstock. Applied Energy, 198, 426-439.

4. Budzianowski W. M., Postawa K. 2017. Renewable energy from biogas with reduced carbon dioxide footprint: Implications of applying different plant configurations and operating pressures. Renewable and Sustainable Energy Reviews, 68, 852-868.

5. CAST (Council for Agricultural Science and Technology). 2011. Carbon sequestration and greenhouse gas fluxes in agriculture: challenges and opportunities. Task Force Report No.142, CAST, Ames, Iowa, USA.

6. Chen H., Fan M., Kuzyakov Y., Billen N., Stahr K. 2014. Comparison of net ecosystem CO2 exchange in cropland and grassland with an automated closed chamber system. Nutr Cycl Agroecosyst, 98:113-124.

7. Crolla A., Kinsley C., Pattey E. 2013. Land application of digestate. in: The biogas handbook. Science, production and application. Woodhead Publishing Series in Energy, Number 52.

8. Czubaszek R., Wysocka-Czubaszek A. 2018. Emissions of carbon dioxide and methane from fields fertilized with digestate from an agricultural biogas plant. Int. Agrophys., 32, 29-37.

9. Eugster W., Merbold L. 2015. Eddy covariance for quantifying trace gas fluxes from soils. Soil, 1, 187-205.

10. Gelfand I., Robertson G. P. 2015. Mitigation of greenhouse gas emissions in agricultural ecosystems. Pages 310-339. In: Hamilton S. K., Doll J. E., Robertson G. P. (Eds.). The Ecology of Agricultural Landscapes: Long-Term Research on the Path to Sustainability. Oxford University Press, New York, New York, USA.

11. Hafner S., Unteregelsbacher S., Seeber E., Lena B., Xu XL., Li XG., Guggenberger G., Miehe G., Kuzyakov Y. 2012. Effect of grazing on carbon stocks and assimilate partitioning in Tibetan montane pasture revealed by $13 \mathrm{CO} 2$ pulse labeling. Glob. Change Biol., 18, 528-538.

12. Gerin P. A., Vliegen F., Jossart J-M. 2008. Energy and $\mathrm{CO} 2$ balance of maize and grass as energy crops for anaerobic digestion. Bioresource Technology, 99, 2620-2627.

13. Hamelin L., Naroznova I., Wenzel H. 2014. Environmental consequences of different carbon alternatives for increased manure-based biogas. Applied Energy, 114, 774-782.

14. KOBIZE. 2016. Poland's national inventory report 2016. Greenhouse Gas Inventory for 1988-2014. [online]: http://www.kobize.pl/uploads/materialy/ materialy_do_pobrania/ krajowa_inwentaryzacja_ emisji/NIR_2016_POL_05.2016.pdf.

15. LDB. 2018. Growing of crops (Growing of other selected crops). Local Data Bank. Central Statistical Office, Warsaw, https://bdl.stat.gov.pl/BDL/ dane/podgrup/tablica.

16. Lei HM, Yang DW. 2010. Seasonal and interannual variations in carbon dioxide exchange over a 
cropland in the North China Plain. Global Change Biol., 16, 2944-2957.

17. Nkoa R. 2014. Agricultural benefits and environmental risks of soil fertilization with anaerobic digestates: a review. Agronomy for Sustainable Development. Springer Verlag/ EDP Sciences/INRA, 34(2), 473-492.

18. Oertel C., Matschullat J., Zurbaa K., Zimmermanna F., and Erasmi S. 2016. Greenhouse gas emissions from soils - A review. Chemie der Erde, 76, 327-352.

19. Pawłowski A., Pawłowska M., Pawłowski L. 2017. Mitigation of greenhouse gases emissions by management of terrestrial ecosystem. Ecol. Chem. Eng S., 24(2), 213-221.

20. Pezzolla D., Bol R., Gigliotti G., Sawamoto T., López A. L., Cardenas L. Chadwick D. 2012. Greenhouse gas (GHG) emissions from soils amended with digestate derived from anaerobic treatment of food waste. Rapid Commun. Mass Spectrom., 26, 2422-2430.

21. Reichstein M., Stoy P.C., Desai A.R., Lasslop G., Richardson A.D. 2012. Partitioning of net fluxes. In: Aubinet M., Vesala T., Papale D. (Eds.). Eddy covariance: a practical guide to measurement and data analysis. Dordrecht: Springer.

22. Reisinger, A., Havlik, P., Riahi, K., van Vliet, O., Obersteiner, M., Herrero, M. 2013. Implications of alternative metrics for global mitigation costs and greenhouse gas emissions from agriculture. Clim. Chang., 117, 677-690.
23. Smith, P., Bustamante,M., Ahammad, H., et al. 2014. Agriculture, Forestry and Other Land Use (AFOLU). In: Edenhofer, O., Pichs-Madruga, R., Sokona, Y., et al. (Eds.). Climate Change 2014: Mitigation of Climate Change. Contribution of Working Group III to the Fifth Assessment Report of the Intergovernmental Panel on Climate Change. Cambridge University Press, Cambridge.

24. Szlachta J., Tupieka M. 2013. Analysis of profitability of maize production designated for silage as a substrate for a biogas plant. (In Polish), Inżynieria Rolnicza, Z. 3(145) T.1, 375-386.

25. Tilman D., Balzer C., Hill J., Befort B. L. 2011. Global food demand and the sustainable intensification of agriculture. Proceedings of the National Academy of Sciences USA 108, 20260-20264.

26. Wolf S., Eugster W., Potvin C., Buchmann N. 2011. Strong seasonal variations in net ecosystem $\mathrm{CO} 2$ exchange of a tropical pasture and afforestation in Panama. Agricultural and Forest Meteorology, 151, 1139-1151.

27. WRB. 2015. World reference base for soil resources 2014. Update 2015. World soil resources reports No. 106, FAO, Rome.

28. Xu M., Shang H. 2016. Contribution of soil respiration to the global carbon equation. Journal of Plant Physiology, 203, 16-28.

29. Zhang L., Sun R., Xu Z., Qiao C., Jiang G. 2015. Diurnal and Seasonal Variations in Carbon Dioxide Exchange in Ecosystems in the Zhangye Oasis Area, Northwest China. PLoS ONE, 10(3), e0120660. 